\title{
ANALISIS STILISTIKA PADA LIRIK LAGU SHEILA ON 7 DALAM ALBUM MENENTUKAN ARAH SERTA RELEVANSINYA SEBAGAI BAHAN AJAR DI SMP
}

\author{
Rendy Langgeng Tri Yusniar, Yant Mujiyanto, Sri Hastuti \\ Universitas Sebelas Maret Surakarta \\ Surel: gidibadas@gmail.com
}

\begin{abstract}
Abstrak: Penelitian ini bertujuan untuk mendeskripsikan dan menjelaskan mengenai (1) aspek diksi; (2) aspek gaya bahasa; (3) aspek citraan; dan (4) relevansi sebagai bahan ajar mata pelajaran bahasa Indonesia di SMP yang ada di dalam lirik lagu Sheila On 7 dalam album Menentukan Arah (2008). Jenis penelitian ini adalah deskriptif kualitatif. Hasil penelitian ini menunjukkan bahwa lirik-lirik lagu Sheila On 7 album Menentukan Arah terdiri dari kalimat-kalimat yang dapat diteliti aspek-aspeknya melalui kajian stilistika. Peneliti menemukan unsur-unsur yang terkandung dalam lirik lagu ini dalam kajian stilistika, yang terdiri dari unsur diksi, gaya bahasa atau majas, citraan, dan relevansinya sebagai bahan ajar mata pelajaran bahasa Indonesia di SMP kelas VII. Hasil penelitian ini juga membuktikan bahwa lirik lagu Sheila On 7 dalam album Menentukan Arah dapat dijadikan bahan ajar mata pelajaran bahasa Indonesia di SMP pada materi puisi.
\end{abstract}

Kata kunci: stilistika, lirik lagu, bahan ajar, SMP

\section{STILISTIC ANALYSIS OF SHEILA ON 7 SONG LIRIC IN MENENTUKAN ARAH ALBUMS AND ITS RELEVANCE AS LEARNING MATERIAL IN JUNIOR HIGH SCHOOL}

\begin{abstract}
This study aims to describe and explain about (1) aspects of diction; (2) aspects of the style of language; (3) aspects of the image; and (4) relevance as teaching material of Indonesian language subjects in junior high school which is in the lyrics of Sheila On 7 in the album Determining the Direction (2008). The type of this research is descriptive qualitative. The results of this study indicate that the lyrics of the song Sheila On 7 album Determine the Direction consists of sentences that can be examined its aspects through stilistic studies. The researchers found the elements contained in the lyrics of this song in the study of stilistika, which consists of diction elements, language style or majas, images, and relevance to teaching materials of Indonesian subjects in SMP class VII. The results of this study also proves that the lyrics of the song Sheila On 7 in the album Determining the Direction can be used as subjects of Indonesian language subjects in junior high school in poetry material.
\end{abstract}

Key words: stylists, song lyrics, teaching materials, junior high school

\section{PENDAHULUAN}

Karya sastra adalah tuangan imajinasi antara manusia dan kehidupannya. Wellek dan Warren (2013: 3) mengatakan sastra adalah suatu kegiatan kreatif, sebuah karya. Sastra berfungsi sebagai karya seni yang bisa digunakan sebagai sarana menghibur diri pembaca maupun pendengar. Karya sastra tidak lepas dari keindahan kalimat-kalimat yang tersemat di dalamnya. Salah satu kajian yang membahas keindahan tersebut adalah kajian stilistika.

Stilistika (stylistic) adalah ilmu tentang gaya, sedangkan stil (style) secara umum adalah cara-cara yang khas, bagaimana segala sesuatu diungkapkan dengan cara tertentu, sehingga tujuan yang dimaksudkan dapat dicapai secara maksimal (Ratna, 2009: 3). Satoto (2012: 6) juga mengatakan bahwa stilistika merupakan 
bidang linguistik yang mengemukakan teori dan metodologi pengkajian atau penganalisisan formal sebuah teks sastra, termasuk dalam pengertian extended. Selain itu, Sehandi (2014: 127) mengemukakan teori stilistika adalah teori sastra yang bertujuan menganalisis atau mengkaji karya sastra dari segi penggunaan bahasa dan gaya bahasanya.

Pembahasan stilistika terbagi menjadi diksi, gaya bahasa dan citraan. Diksi dapat dikatakan sebagai kata. Diksi sering diartikan sebagai pilihan kata yang digunakan pengarang untuk mengatur jalan cerita yang diinginkan. Nurgiyantoro (2002: 390) mengungkapkan pemilihan kata-kata tentunya melalui pertimbanganpertimbangan tertentu untuk mendapatkan efek yang dikehendaki. Selain diksi, unsur stilistika lainnya adalah gaya bahasa. Gaya bahasa merupakan suatu hal yang menarik untuk dikaji di dalam sebuah karya sastra. Gaya bahasa merupakan sarana strategis yang seringkali dipilih pengarang untuk mengungkapkan pengalaman kejiwaannya ke dalam karya fiksi. Dalam bukunya, Satoto (2012: 150) menyatakan hakikat gaya (style), tidak lain adalah cara mengungkapkan diri sendiri, entah melalui bahasa, tingkah laku, berpakaian dan sebagainya. Unsur stilistika yang lain adalah citraan. Pradopo (1993: 79) mengatakan gambaran-gambaran angan dalam sajak itu disebut citraan (imagery). Citraan berwujud peenggambaran sesuatu melalui suatu ungkapan yang dapat dilakukan dengan baik melalui ungkapan yang mampu merangsang indra manusia.

Salah satu bentuk karya sastra yang di dalamnya terdapat unsur-unsur stilistika adalah lagu. Lagu merupakan kumpulan atau rangkaian kata-kata yang indah yang dinyanyikan dengan iringan musik (Uli, dkk, 2016). Lagu dibuat berdasarkan komposisi musik dan memiliki irama serta tempo agar para pendengar ikut terbawa suasana ke dalam lagu tersebut. Lagu dan puisi sama- sama merupakan karya sastra yang diciptakan berdasarkan khayalan dan imajinasi seseorang yang bertujuan untuk mengungkapkan isi hati. Fungsi dari lagu sebagai media komunikasi seperti bersimpati tentang realitas dan cerita imajinatif. Selain itu, lagu juga dapat berfungsi sebagai media untuk menyampaikan pikiran atau perasaan kepada orang lain. Lirik lagu merupakan teks yang berupa kumpulan kata-kata, yang merupakan tuangan gagasan dan perasaan pengarang. Di dalam lirik lagu terdapat pesan-pesan, maupun makna yang dapat diambil.

Dalam penelitian ini, penulis memilih lagu-lagu dari Sheila On 7 di album Menentukan Arah, yang di dalamnya terdapat sepuluh lagu. Grup band ini terkenal dengan lirik lagu yang easy listening, sederhana, dan sering memberikan sentuhansentuhan kias dalam setiap lagunya. Selain untuk dihafalkan dan dinyanyikan, lirik lagu Sheila On 7 dapat digunakan sebagai bahan ajar di mata pelajaran Bahasa Indonesia karena banyak mengandung nilai-nilai estetika. Lirik lagu pada album Menentukan Arah juga terdapat diksi, gaya bahasa, dan citraan yang dapat dikaji. Hal ini sangat mendukung untuk dijadikan bahan ajar pembelajaran sastra di sekolah.

Sebagaimana yang dikemukakan Slamet (2007: 6), bahwa pengajaran bahasa Indonesia adalah pengajaran keterampilan berbahasa bukan pengajaran tentang kebahasaan. Pada kurikulum 2013, pembelajaran Bahasa Indonesia diorientasikan pada pembelajaran berbasis teks. Menurut Mahsun (dalam Meza, Mustofa, \& Karomani, 2015) teks wujudnya dapat berupa bahasa yang dituturkan atau dituliskan, atau juga bentuk-bentuk sarana lain yang digunakan untuk menyatakan apa saja yang dipikirkan. Teks merupakan ungkapan pikiran manusia yang lengkap yang di dalamnya memiliki situasi dan konteks. Dengan demikian, analisis yang 
mendalam mengenai sebuah teks tentunya penting dilakukan untuk dapat memahami teks tersebut. Salah satu teks yang dipelajari oleh siswa SMP kelas VII adalah teks puisi.

Dari pemaparan di atas dapat disimpulkan bahwa pembahasan stilistika tidak hanya terdapat di dalam novel atau cerpen, namun juga di dalam lirik lagu. Lirik lagu merupakan salah satu bentuk karya sastra yang memiliki peluang untuk dijadikan bahan ajar di sekolah, mengingat keberadan lagu sangat dekat dengan masyarakat bahkan sudah menjadi bagian dari kehidupan. Adanya lirik lagu dapat mempermudah guru untuk menemukan bahan ajar, serta mampu untuk meningkatkan kreativitas siswa dalam menelaah diksi, gaya bahasa, dan citraan yang sesuai dengan KI dan KD di sekolah.

Berdasarkan latar belakang tersebut, sangat beralasan bagi peneliti untuk melakukan penelitian terhadap lirik lagu dalam album Menentukan Arah karya Sheila On 7 dengan judul "Analisis Stilistika pada Lirik Lagu Sheila On 7 dalam Album Menentukan Arah serta Relevansinya sebagai Bahan Ajar di SMP”.

\section{METODE PENELITIAN}

Penelitian ini merupakan penelitian deskriptif kualitatif dengan menggunakan kajian stilitika. Data dan sumber data yang digunakan pada penelitian ini adalah dokumen dan informan. Dokumen yang merupakan sumber data primer adalah lirik lagu Sheila On 7 dalam album Menentukan Arah yang dirilis pada tahun 2008. Sedangkan informan yang digunakan pada penelitian ini adalah guru Bahasa Indonesia. Teknik sampling yang digunakan dalam penelitian ini adalah purposive sampling. Teknik pengumpulan data yang digunakan dalam penelitian ini adalah teknik analisis dokumen, catat, dan wawancara. Teknik uji validitas data menggunakan triangulasi teori dan teknik triangulasi sumber data. Analisis data dalam penelitian ini menggunakan model analisis jalinan atau mengalir, yaitu (1) reduksi data, (2) penyajian data, (3) penarikan kesimpulan. Prosedur penelitian ini meliputi beberapa tahap, yakni: tahap persiapan, tahap pelaksanaan dan tahap penyusunan laporan.

\section{HASIL DAN PEMBAHASAN \\ Pilihan kata dalam album Menentukan Arah karya Sheila On 7}

Penggunaan diksi yang akan diteliti meliputi: kata sapaan khas nama diri, kata vulgar, kata serapan, dan kata dengan objek realitas alam.

\section{Penggunaan Diksi Kata Sapaan Khas Nama Diri}

Kata merupakan suatu unit dalam bahasa yang memiliki stabilitas intern dan mobilitas posisional, yang berarti ia memiliki komposisi tertentu (entah fonologis entah morfologis) dan secara relatif memiliki distribusi yang bebas (Keraf, 2010:21). Sementara pendapat lain mengatakan bahwa diksi adalah kata-kata mana yang dipakai untuk mengungkapkan suatu ide yang mencakup fraseologi, majas, dan ungkapan. Fraseologi mencakup persoalan kata-kata dalam pengelompokan atau susunannya, atau cara khusus berbentuk ungkapan (Al-Ma'ruf, 2009:50).

Penggunaan kata sapaan khas nama diri yang ditemukan dalam album Menentukan Arah karya Sheila On 7 meliputi: Aku, Kau, Bidadari, Ibundanya, Tuhan, Wanita, Lelaki, Mereka, Kita, dan Dia.

$A k u$

"tolong bantu $a k u$ melewati semua"

Dalam kutipan tersebut, kata "aku" merujuk pada tokoh utama. Penyair bermaksud agar dia dibantu untuk melewati kesedihan yang dialaminya. $\mathrm{Kau}$

"Dimana kau sekarang" 
Kata sapaan "kau" di atas merupakan penanda untuk tokoh kedua. Kutipan tersebut menjelaskan tentang penyair yang ingin mengetahui keberadaan kekasihnya yang sudah lama tidak bertemu.

Bidadari

"Bidadari yang kunanti" (dalam lagu Yang Terlewatkan)

Kata sapaan "bidadari" merujuk pada tokoh kedua. Pada lirik lagu tersebut digambarkan tentang seorang perempuan yang hadir, disaat penyair benar-benar mengharapkannya.

Ibundanya

"Ibundanya menerima teleponku" (dalam lagu Ibu Linda)

Kata sapaan "Ibundanya" dalam kalimat di atas merujuk pada tokoh ketiga. Pada lirik lagu tersebut diceritakan pengalaman penyair yang sedang merindukan pujaan hati dan berusaha menelepon rumahnya, namun diangkat oleh orang tua kekasihnya, yang dalam lagu tersebut dikisahkan bahwa orang tua tokoh kedua tidak merestui hubungan mereka.

Tuhan

"Tuhan aku berjalan menyusuri malam" (dalam lagu Mudah Saja)

Pada kutipan di atas terdapat penggunaan diksi sapaan. Kata sapaan "Tuhan" merupakan penanda pencipta alam, yang dalam lagu tersebut penyair berusaha menceritakan tentang kisah patah hati yang dialami.

Wanita

"Dimana kan kutemukan wanita sepertimu" (dalam lagu Arah)

Kata sapaan "wanita" merupakan penanda untuk tokoh kedua. Dalam lirik tersebut diceritakan bahwa penyair yang begitu bahagia karena mendapatkan seorang perempuan yang sangat diharapkannya.

\section{Lelaki}

"Akulah lelaki" (dalam lagu Alasanku)

Kata sapaan "lelaki" merupakan penanda untuk tokoh utama, yaitu penyair. Dalam lirik tersebut dijelaskan tentang perasaan penyair yang tak bisa dewasa tanpa kekasihnya, yang dijelaskan di lirik selanjutnya.

Mereka

"Mereka memisahkan" (dalam lagu Ibu Linda)

Kata sapaan "mereka" pada lirik tersebut merujuk kepada orang tua kekasih tokoh utama, yaitu penyair, yang berusaha memisahkan mereka.

Kita

"Kita selalu bersama" (dalam lagu Yang Terlewatkan)

Kata sapaan "kita" pada lirik tersebut merujuk kepada tokoh utama (penyair) dan tokoh kedua. Lirik tersebut menjelaskan bahwa tokoh utama dan tokoh kedua saling mencintai dan selalu bersama, namun orang tua tokoh kedua berusaha memisahkan yang dijelaskan lirik selanjutnya.

Dia

"Dia bilang" (dalam lagu Mudah Saja)

Kata sapaan "dia" pada lirik tersebut merujuk kepada tokoh kedua. Lirik tersebut menjelaskan ketika tokoh kedua berbicara kepada tokoh utama, yang dijelaskan pada lirik selanjutnya.

\section{Penggunaan Diksi Kata Vulgar}

Kata vulgar adalah penyebutan secara ilmiah untuk kata yang kasar atau tidak baik untuk diucapkan. Kata vulgar adalah katakata yang tidak intelek, kurang beradab, dipandang tidak etis, dan melanggar sopan santun di kalangan masyarakat intelek dan terpelajar (Al Maruf, 2009:57).

Dalam penelitian ini penggunaan kata vulgar yang digunakan Sheila On 7 hanya ditemukan satu kata yaitu bodoh.

Bodoh 
"Betapa bodoh diriku" (dalam lagu Arah)

Dari lirik lagu tersebut dapat dilihat terdapat kata vulgar yaitu kata "bodoh". Kata "bodoh" merupakan kata yang tidak baik diucapkan di masyarakat karena terdengar kasar dan tidak mendidik.

\section{Penggunaan Diksi Kata Serapan}

Kata serapan merupakan kata asing yang telah diserap menjadi kosakata Bahasa Indonesia. Kata serapan adalah kata yang diambil atau dipungut dari bahasa lain, baik bahasa asing maupun basa daerah, baik mengalami adaptasi struktur, tulisan dan lafal, maupun tidak dan sudah dikategorikan sebagai kosakata Bahasa Indonesia (AlMa'ruf, 2009:56).

Dalam penelitian ini penggunaan kata serapan yang digunakan Sheila On 7 hanya ditemukan satu kata yaitu telfon.

Telfon

"Ibundanya menerima telfon ku" (dalam lagu Ibu Linda)

Dari lirik lagu tersebut dapat ditemukan kata serapan yaitu kata "telfon" yang dalam bahasa Indonesia berarti melakukan komunikasi. Dalam konteks lirik lagu di atas diceritakan tokoh utama yang berusaha mencari kekasih dengan cara menelepon rumahnya. Akan tetapi, yang menerima panggilan adalah ibunda kekasihnya, yang dalam lagu tersebut diceritakan bahwa hubungan mereka tidak direstui.

\section{Penggunaan Diksi Kata dengan Objek Realitas Alam}

Kata dengan objek realitas alam adalah kata yang memanfaatkan realitas alam sebagai bentukan kata tertentu yang memiliki arti. Maknanya tentu saja dapat dipahami dengan melihat konteks kalimat atau melihat hubungan kata dengan kata lainnya dalam satua kebahasaan dengan memperhatikan realitas alam yang digunakan (Al-Ma'ruf, 2009: 126). Sementara pendapat lain mengatakan bahwa yang menjadi objek utama secara langsung dari estetika adalah keindahan-baik keindahan alam maupun keindahan seni (Satoto, 2012:30). Kata dengan objek realitas alam yang ditemukan dalam album Menentukan Arah meliputi: bulan purnama dan palung lautan.

\section{Bulan purnama}

"Sepucat bulan purnama" (dalam lagu Jalan Keluar)

Pada lagu Jalan Keluar, penyair menggunakan kata bulan purnama untuk menggambarkan suasana malam hari. Kata tersebut digunakan penyair sebagai ungkapan perumpamaan, tentang kesedihan hati yang mendalam.

\section{Palung lautan}

"Sedalam palung lautan" (dalam lagu Jalan Keluar)

Pada kutipan lirik lagu di atas terdapat dua kata dengan objek realitas alam. Kata yang pertama yaitu kata "palung" yang berarti tempat yang sangat dalam. Kata selanjutnya yaitu kata "lautan" yang berarti laut yang sangat luas. Katakata tersebut digunakan penyair sebagai ungkapan perumpamaan perasaan kepada perempuan yang dicintainya.

\section{Gaya Bahasa dalam Album Menentukan Arah Karya Sheila On 7}

Hakikat gaya (style) adalah cara mengungkapkan diri sendiri, entah melalui bahasa, tingkah laku, berpakaian dan sebagainya. Gaya bahasa sebenarnya merupakan bagian dari pilihan kata atau diksi yang mempersoalkan cocok-tidaknya pemakaian kata (Satoto, 2012: 150).

Gaya bahasa dapat dikatakan sebagai keahlian seorang pengarang dalam mengolah kata-kata. Jangkauan gaya bahasa sangat luas, tidak hanya menyangkut masalah kata, 
tetapi juga rangkaian dari kata-kata tersebut yang meliputi frasa, klausa, kalimat, dan wacana secara keseluruhan. Tercapainya tujuan karena adanya keunikan pada pemakaian bahasa, terutama pada aspek bentuk. Semakin bentuk pemakaian bahasa yang baik maka semakin besar tujuan pengirim pesan tercapai.

Dari hasil penelitian yang dilakukan, album Menentukan Arah karya Sheila On 7 ditemukan hasil penggunaan gaya bahasanya sebagai berikut: gaya bahasa asonansi sebanyak 14 data, gaya bahasa repetisi sebanyak 8 data dan gaya bahsa anafora sebanyak 11 data. Selain itu ditemukan pula beberapa jenis majas ang dipakai dalam liriklirik lagu tersebut. Beberapa contoh gaya bahasa yang ditemukan, yaitu: Asonansi

Kini kau telah menjalani

Asonansi yang terdapat dalam kutipan lirik lagu tersebut yakni perulangan bunyi vokal /i/ pada lirik /kini/ dan /menjalani/.

Lukamu seperti lukaku

Asonansi yang terdapat dalam kutipan lirik lagu tersebut yakni perulangan bunyi vokal /u/ pada lirik /lukamu/ dan /lukaku/.

\section{Repetisi}

Cinta mu seperti cinta ku

Repetisi yang terdapat dalam kutipan lirik lagu tersebut yakni perulangan kata /cinta/ pada satu konteks yang sesuai.

\section{Anafora}

Dimana kau sekarang

Apa yang telah terjadi

Dimana kau sekarang

Apa yang kau alami

Anafora yang terdapat dalam

kutipan lirik lagu tersebut yakni perulangan kata /dimana/ dan kata lapa/ yang merupakan kata pertama dari baris tersebut.

\section{Personifikasi}

"Sepucat bulan purnama" (dalam lagu Jalan Keluar)

Pada kutipan di atas terdapat gaya bahasa personifikasi. Gaya bahasa personifikasi dalam lirik ini terletak pada kata "sepucat" yang dikenakan tindakan yang seharusnya untuk manusia.

\section{Hiperbola}

"Sedalam jurang hatimu" (dalam lagu Jalan Keluar)

Pada kutipan di atas terdapat gaya bahasa hiperbola karena adanya pengungkapan yang berlebihan dan tidak masuk akal berupa "jurang hatimu". Maksud dari kalimat di atas yaitu menjelaskan tentang perasaan penyair yang dilepaskan kekasihnya terlalu jauh.

"Aku terbakar bahagia" (dalam lagu Lia Lia Lia)

Pada kutipan di atas terdapat gaya bahasa hiperbola karena adanya pengungkapan yang berlebihan dan tidak masuk akal berupa "terbakar bahagia". Maksud dari kalimat di atas yaitu menjelaskan penyair yang sangat bahagia dapat dipertemukan dengan Lia.

\section{Satire}

"Bidadari yang kunanti" (dalam lagu Yang Terlewatkan)

Pada kutipan di atas terdapat penggunaan gaya bahasa satire. Hal ini dibuktikan dari penggalan lirik "bidadari yang kunanti". Konteks kutipan di atas menjelaskan tentang perempuan dambaan penyair. 
Ironi

"Ku masih sembunyi di balik senyum palsu" (dalam lagu Betapa)

Pada kutipan di atas terdapat penggunaan gaya bahasa ironi. Hal ini dibuktikan adanya pertentangan dari apa yang ditunjukkan dengan apa yang dirasakan. Konteks kutipan di atas menjelaskan penyair yang hanya berpura-pura tersenyum di depan teman-teman yang berusaha menghiburnya.

\section{Sinisme}

"Kau tak berhak tanyakan hidupku" (dalam lagu Mudah Saja)

Pada kutipan di atas terdapat gaya bahasa sinisme. Hal ini dibuktikan dengan lirik di atas yang menjelaskan bahwa penyair tidak suka dengan pertanyaan mantan kekasih yang menyangkut dirinya, karena terlanjur kecewa.

\section{Pleonasme}

"Jika saja waktu bisa terulang" (dalam lagu Arah)

Kalimat di atas dikategorikan sebagai gaya bahasa pleonasme karena dalam kalimat tersebut menggunakan kata yang kurang efektif. Hal tersebut dapat dilihat pada kata jika saja. Kata tersebut dapat diganti dengan menghilangkan kata saja.

\section{Citraan dalam Album Menentukan Arah Karya Sheila On 7}

Citraan merupakan salah satu hal selain diksi dan gaya bahasa yang dapat membuat suatu karya sastra menjadi lebih hidup. Pencitraan pada sebuah karya fiksi merupakan gambaran imajinasi yang timbul karena efek diksi yang dipilih oleh pengarang, yang akan membuat penikmat sastra seakan-akan ikut merasakan langsung bagaimana kejadian itu terjadi. Al-Ma'ruf (2009:78) berpendapat bahwa dalam tangan sastrawan yang baik imaji itu segar dan hidup, berada pada puncak keindahannya untuk mengintensifkan, menjernihkan, merasakan pengalaman pengarang terhadap objek dan situasi yang dialaminya, memberi gambaran yang setepatnya, hidup kuat, ekonomis, dan segera dapat dirasakan dan dekat dengan kehidupan pembaca. Pemanfaatan citraan dalam Album Menentukan Arah karya Sheila On 7 sangat seimbang dengan hasil yang ditemukan yaitu citraan penglihatan (4), citraan pendengaran (4), dan citraan gerak (4). Beberapa contoh citraan yang ditemukan yaitu:

\section{Citraan Penglihatan}

"Melihatmu" (dalam lagu Yang Terlewatkan)

Pada kutipan di atas terdapat penggunaan citraan penglihatan. Hal ini terbukti dari penggalan lirik lagu di atas yang menjelaskan tentang penyair yang masih mengagumi mantan kekasihnya, yang dijelaskan di lirik selanjutnya.

\section{Citraan Pendengaran}

"Mendengarmu" (dalam lagu Yang Terlewatkan)

Pada kutipan di atas terdapat penggunaan citraan pendengaran. Hal ini dibuktikan dari indra pendengaran yang digunakan oleh penyair. Penggalan lirik di atas menjelaskan mantan kekasih penyair masih menjadi yang terhebat dalam hidupnya walaupun sudah tak lagi bersama.

\section{Citraan Gerak}

"Aku berjalan menyusuri malam" (dalam lagu Mudah Saja)

Pada kutipan di atas terdapat penggunaan citraan gerak. Hal ini dijelaskan dari penggalan lirik tersebut yang menceritakan ketika penyair 
sedang berjalan di waktu malam hari setelah mengalami patah hati.

\section{Relevansi Lirik Lagu dalam Album Menentukan Arah Karya Sheila On 7 sebagai Bahan Ajar Bahasa Indonesia di SMP}

Widodo \& Jasmadi (dalam Lestari, 2013: 1) menjelaskan bahan ajar adalah seperangkat sarana atau alat pembelajaran yang berisikan materi pembelajaran, metode, batasan-batasan, dan cara mengevaluasi yang didesain secara sistematis dan menarik dalam rangka mencapai tujuan yang diharapkan, yaitu mencapai kompetensi atau subkompetensi dengan segala kompleksitasnya. Bahan ajar dalam pembelajaran yang akan digunakan dapat berupa buku sumber utama atau buku penunjang lainnya. Selain itu, Prastowo (2013: 296) juga menambahkan bahan ajar penunjang dapat berupa jurnal, hasil penelitian, majalah, koran, brosur, serta alat pembelajaran yang terkait dengan indikator dan kompetensi dasar yang ditetapkan.

Berdasarkan hasil wawancara dari informan dan pemaparan dari berbagai sumber, album Menentukan Arah relevan sebagai bahan ajar karena bahasa yang digunakan adalah bahasa remaja saat ini sehingga mudah dipahami. Album ini juga menggunakan bahasa sehari-hari yang mudah dipahami siswa. Kemudian istilahistilah dari album ini tidak jauh dari perkembangan teknologi modern. Secara psikologis, album Menentukan Arah ini sesuai dengan psikologis siswa kelas VII SMP, hal tersebut dapat dibuktikan dengan tema yang ada dalam cerita yang tidak terlalu berat untuk siswa kelas VII SMP. Secara sosiologis, album ini mengambil tema dan konflik berlatarkan lingkungkan remaja sehingga siswa tidak terlalu sulit untuk memahami isi dari album ini.

Berdasarkan lirik-lirik lagu yang terdapat dalam album Menentukan Arah, siswa dapat mempelajari beberapa aspek penting yang berkaitan dengan puisi, misalnya diksi, majas, gaya bahasa, citraan, dan lain sebagaiya. Oleh karena itu, lirik lagu tersebut relevan apabila digunakan sebagai bahan ajar Bahasa Indonesia di SMP.

\section{SIMPULAN}

Berdasarkan hasil analisis data dan pembahasan yang telah diuraikan di atas, dapat disimpulkan bahwa lirik lagu yang terdapat dalam album Menentukan Arah Sheila On 7 memanfaatkan berbagai aspek atau unsur bahasa. Aspek yang pertama yaitu diksi. Ditemukan data berupa kata sapaan khas nama diri sebanyak (10), kata serapan (1), kata vulgar (1), dan kata objek realitas alam (2) dalam album tersebut. Kemudian dari aspek kedua yaitu gaya bahasa. Dalam album Menentukan Arah karya Sheila On 7 ditemukan gaya bahasa asonansi sebanyak 14 data, gaya bahasa repetisi sebanyak 8 data dan gaya bahasa anafora sebanyak 11 data, serta beberapa majas, yaitu majas personifikasi (3), majas hiperbola (10), majas satire (1), majas ironi (3), majas sinisme (1), dan majas pleonasme (3). Aspek yang ketiga adalah citraan. Pemanfaatan citraan dalam Album Menentukan Arah karya Sheila On 7 sangat seimbang dengan hasil yang ditemukan yaitu citraan penglihatan (4), citraan pendengaran (4), dan citraan gerak (4).

Relevansi album Menentukan Arah Sheila On 7 sebagai bahan ajar Bahasa Indonesia di SMP yaitu diperoleh hasil bahwa album Menentukan Arah Sheila On 7 dapat digunakan sebagai bahan ajar Bahasa Indonesia di kelas VII SMP. Hal tersebut sesuai dengan kriteria dalam penggunaan sebuah materi ajar yang harus mencakup aspek komunikasi puisi, khususnya pada pelajaran Bahasa Indonesia di kelas VII. Sesuai dengan kompetensi dasar yang terdapat dalam silabus di kelas VII SMP. 
mencakup aspek bahasa yang baik.

\section{REFERENSI}

Al-Ma'ruf, A. I. (2009a). Stilistika: Teori, Metode, dan Aplikasi Pengkajian Estetika Bahasa. Surakarta: Cakrabooks.

Keraf, G. (2010). Diksi dan Gaya Bahasa. Jakarta: Gramedia Pustaka Utama.

Lestari, I (2013). Pengembangan Bahan Ajar Berbasis Kompetensi. Padang: Akademia Permata

Meza, Yuspa Fitri., Mustofa, Ali., \& Karomani. (2015). Pembelajaran Menulis Teks Ulasan pada Siswa Kelas VIII SMP Negeri 4 Metro Tahun Pelajaran 2014/2015.

Nurgiyantoro, B. (2002). Teori Pengkajian Fiksi. Yogyakarta: Gajah Mada University Press.

Pradopo, R. (1993). Pengkajian Puisi Analisis Strata Norma dan Analisis Struktural dan Semiotik. Yogyakarta: Gadjah Mada University Press.

Prastowo, Andi. (2013). Pengembangan Bahan Ajar Tematik. Yogyakarta: DIVA Press (Anggota IKAPI).
Ratna, N.K. (2009). Stilistika: Kajian Puitika Bahasa, Sastra, dan Budaya. Yogyakarta: Pustaka Pelajar.

Satoto, S. (2012). Stilistika. Yogyakarta: Penerbit Ombak

Sehandi, Yohanes. (2014). Mengenal 25 Teori Sastra. Yogyakarta: Penerbit Ombak.

Slamet, St. Y. (2007). Dasar-Dasar Pembelajaran Bahasa dan Sastra Indonesia di Sekolah Dasar. Surakarta: LPP UNS dan UPT.

Uli, I., Wiguna, Z K., Agustina, R. (2016) Analisis Gaya Bahasa pada Lirik Lagu Daerah Pontianak dan Pemanfaatannya sebagai Bahan Pembelajaran Apresiasi Puisi di SMA. Jurnal Pendidikan Bahasa. Volume 5 Nomor 1 Juni 2016

Wellek, R. \& Austin, W. (2013). Teori Kesusastraan. Jakarta: PT Gramedia Pustaka Utama. 